\title{
Millennial-scale climate variability recorded in
}

\section{Brazilian speleothems}

Xianfeng Wang ${ }^{1}$, F.W. Cruz ${ }^{2}$, A.S. Auler ${ }^{3}$, H. Cheng ${ }^{1}$ and R.L. Edwards ${ }^{1}$

'Department of Geology and Geophysics, University of Minnesota, Minneapolis, USA; wang0452@umn.edu

2Institute of Geosciences, University of Săo Paulo, Brazil

3Institute of Karst Geology, Federal University of Minas Gerais, Belo Horizonte, Brazil

There is steadily increasing interest in obtaining records of millennial-scale climate events in speleothems (McDermott et al., 2005 and references therein), as they have the potential for precise and accurate age control. Brazil comprises extensively developed karst landscapes, which are mainly located in the eastern part of the country (Auler et al., 2001). Over the last ten years, we have successfully collected speleothem samples from Brazil, with particular interest in samples from northeastern and southern Brazil (Fig. 1). The intent was to investigate (1) whether abrupt climate events are recorded in the southern hemisphere, particularly within the southern low latitudes, (2) if recorded, how they relate to their northern counterparts in both low- and high-latitudes, and (3) what kind of mechanisms could explain the overall geographic pattern of any recorded events.

\section{Millennial-scale climate events}

Speleothems and fossil travertine in the presently semi-arid northeastern Brazil suggest that this region experienced enhanced precipitation and groundwater recharge in the past (Auler and Smart, 2001) (Fig. 1). Constrained with a large quantity of U-Th dates, speleothem growth in northeastern Brazil was found to be highly episodic. The growth phases represent millennial-scale short pluvial periods during the last glacial period, whereas sample growth was not observed in dry conditions like today (Wang et al., 2004) (Fig. 2). When compared with the contemporaneous records from the northern hemisphere, these wet periods are synchronous with periods of weak East Asian summer monsoons (Wang et al., 2001), cold events in Greenland (Grootes and Stuiver, 1997), and periods of decreased river runoff to the Cariaco basin (Peterson et al., 2000).

Two continuous speleothem $\delta^{18} \mathrm{O}$ records were reported from Botuverá Cave, southern Brazil (see site 1 in Fig. 1), covering the last $116 \mathrm{kyr}$ and $90 \mathrm{kyr} \mathrm{BP}$, respectively (Cruz et al., 2005; Wang et al., 2007). Both records successfully capture millennial-scale events that are superimposed on the orbital-scale variations during the last glacial period. The abrupt drop in $\delta^{18} \mathrm{O}$ values associated with these millennialscale events is large, with amplitudes of up to $2 \%$. Botuverá stalagmites were deposited in isotopic equilibrium, therefore, the calcite $\delta^{18} \mathrm{O}$ mainly represents a regional change in precipitation regime (Cruz et al., 2005). Moreover, a trace element study on one of the samples shows that variations of $\mathrm{Mg} / \mathrm{Ca}$ and $\mathrm{Sr} / \mathrm{Ca}$ ratios are, in general, positively correlated with the calcite $\delta^{18} \mathrm{O}$ change along the growth axis (Cruz et al., 2007), which confirms that Botuverá stalagmite $\delta^{18} \mathrm{O}$ is dominated by the monsoonal rainfall amount.
Using their individual chronologies, we compared the 90-kyr-long Botuverá $\delta^{18} \mathrm{O}$ record with the eastern China $\delta^{18} \mathrm{O}$ profile, which is a combination of records from Hulu (Wang et al., 2001), Dongge (Yuan et al., 2004; Wang et al., 2005), and Sanbao caves (Wang et al., 2008) (Fig. 2). All records are precisely established with a typical relative $2 \sigma$ age error of about $0.5-1 \%$. Within dating errors, the comparison shows a remarkable anti-correlation between records on both orbital and millennial timescales. Throughout the whole

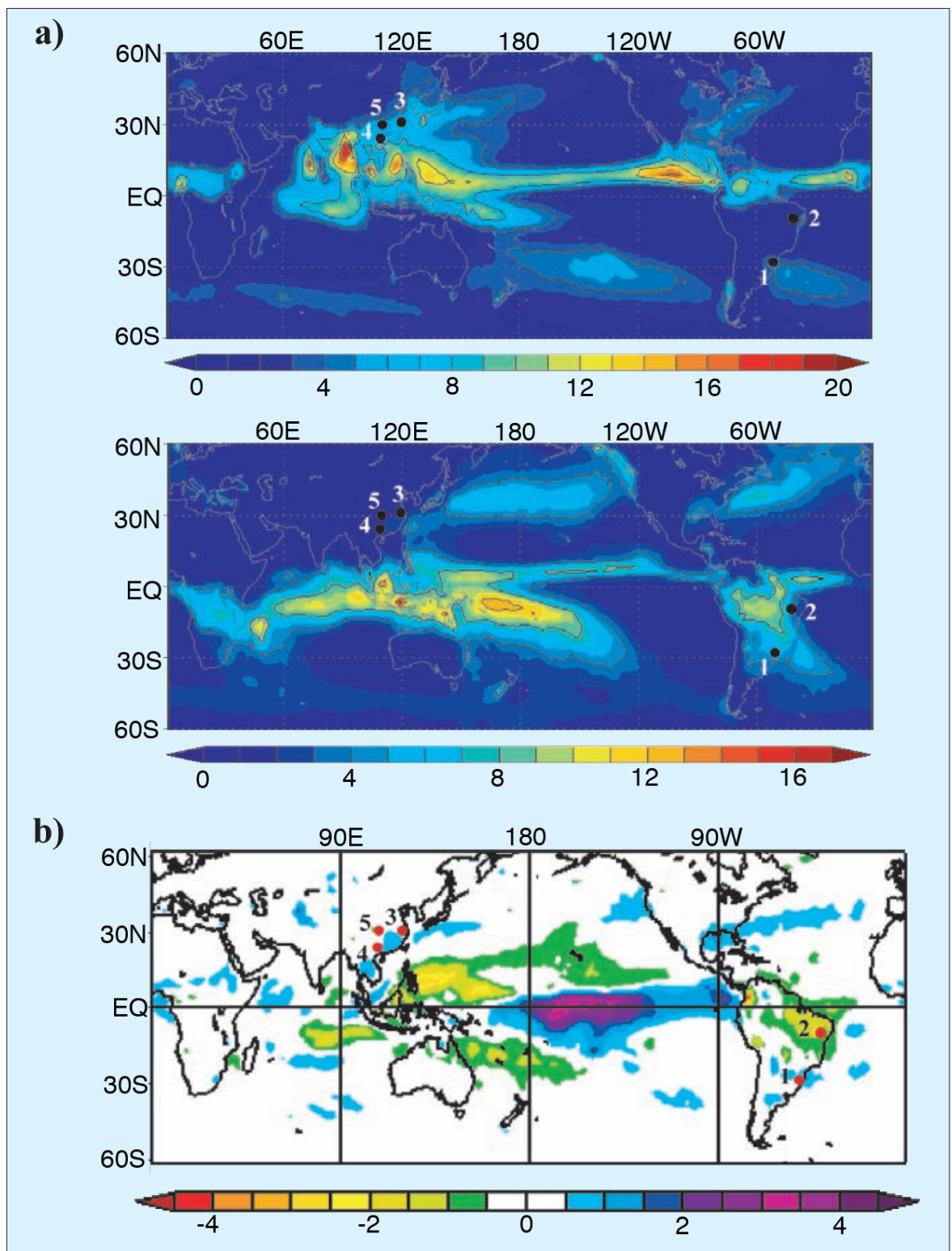

Figure 1: a) Global long-term mean precipitation (mm/day) from 1979 to 2000. Upper: Averaged from June to August (JJA). Lower: Averaged from December to February (DJF). Numbers indicate cave locations in text: 1. Caverna Botuverá; 2. NE. Brazil caves $\left(10^{\circ} 10^{\prime} \mathrm{S}, 40^{\circ} 50^{\prime} \mathrm{W}\right) ; 3$. Hulu Cave $\left(32^{\circ} 30^{\prime} \mathrm{N}, 119^{\circ} 10^{\prime} \mathrm{E}\right)$; 4. Dongge Cave $\left(25^{\circ} 17^{\prime} \mathrm{N}, 108^{\circ} 5^{\prime} \mathrm{E}\right)$; and 5. Shanbao Cave $\left(31^{\circ} 40^{\prime} \mathrm{N}, 110^{\circ} 26^{\prime} \mathrm{E}\right)$. (Images modified from www.cdc.noaa.gov/). b) Composite anomaly of precipitation rate ( $\mathrm{mm} /$ day) during winter (Nov-Mar) associated with 8 El Niño events (1957-1958, 1965-1966, 1968-1969, 1972-1973, 1982-1983, 1986-1987, 1991-1992 and 1997-1998) from 1948 to the present. Anomalies are defined as the difference from the 1968 to1996 means. 
profile, the lower $\delta^{18} \mathrm{O}$ in the Botuverá record coincides precisely with higher $\delta^{18} \mathrm{O}$ in the eastern China speleothems, and vice versa, which indicates a rainfall seesaw between the two low-latitude regions. We also compared our Botuverá $\delta^{18} \mathrm{O}$ record to the record of speleothem growth periods from northeastern Brazil (Wang et al., 2004), which is an indicator of pluvial phases in this semiarid region. The northeastern Brazil speleothem typically resumes growth when $\delta^{18} \mathrm{O}$ values are low in the southern Brazil sample (Wang et al., 2007). Simply speaking, on millennial timescales, rainfall changes in southern Brazil and northeastern Brazil are in phase, and both anti-correlate with precipitation variation in eastern China.

\section{ITCZ migration and climatic consequences}

While the eastern China speleothem $\delta^{18} \mathrm{O}$ profile shares similarities with the Greenland ice core record on millennial-scale climate events (e.g., Wang et al., 2001), southern Brazil rainfall variation does not resemble Antarctic temperature change (Fig. 2). Instead, the millennial-scale precipitation events in the Brazilian record generally anti-correlate with temperature changes over the Greenland. The asynchrony between Greenland and Antarctic warming suggests a possible teleconnection through an oceanic bipolar seesaw process and thermal inertia in the Southern Ocean (e.g., Stocker and Johnsen, 2003; Jouzel et al., 2007). The striking antiphase relationship between the Chinese and Brazilian records, however, suggests that the signal needs to be transmitted in a relatively rapid manner between the two low latitudes. Therefore, atmospheric interactions must be involved, likely through movement in the mean position of the intertropical convergence zone (ITCZ) and associated change in Hadley circulation.

During the last glacial period, an abrupt reduction in the Atlantic meridional overturning circulation (AMOC) induced sea ice expansion in the North Atlantic and a subsequent southward displacement of the ITCZ (e.g., Chiang et al., 2003; Zhang and Delworth, 2005). This may have caused an abrupt shift in the tropical hydrologic cycle, as seen in the Cariaco Basin (Peterson et al., 2000) and northeastern Brazil (Wang et al., 2004). Modeling efforts also indicate that weak ocean circulation may result in a positive sea surface temperature (SST) anomaly in the South Atlantic and a weaker pole-to-equator temperature gradient in the south (e.g., Crowley, 1992). As observed today (Liebmann et al., 2004), a warm SST anomaly in the western

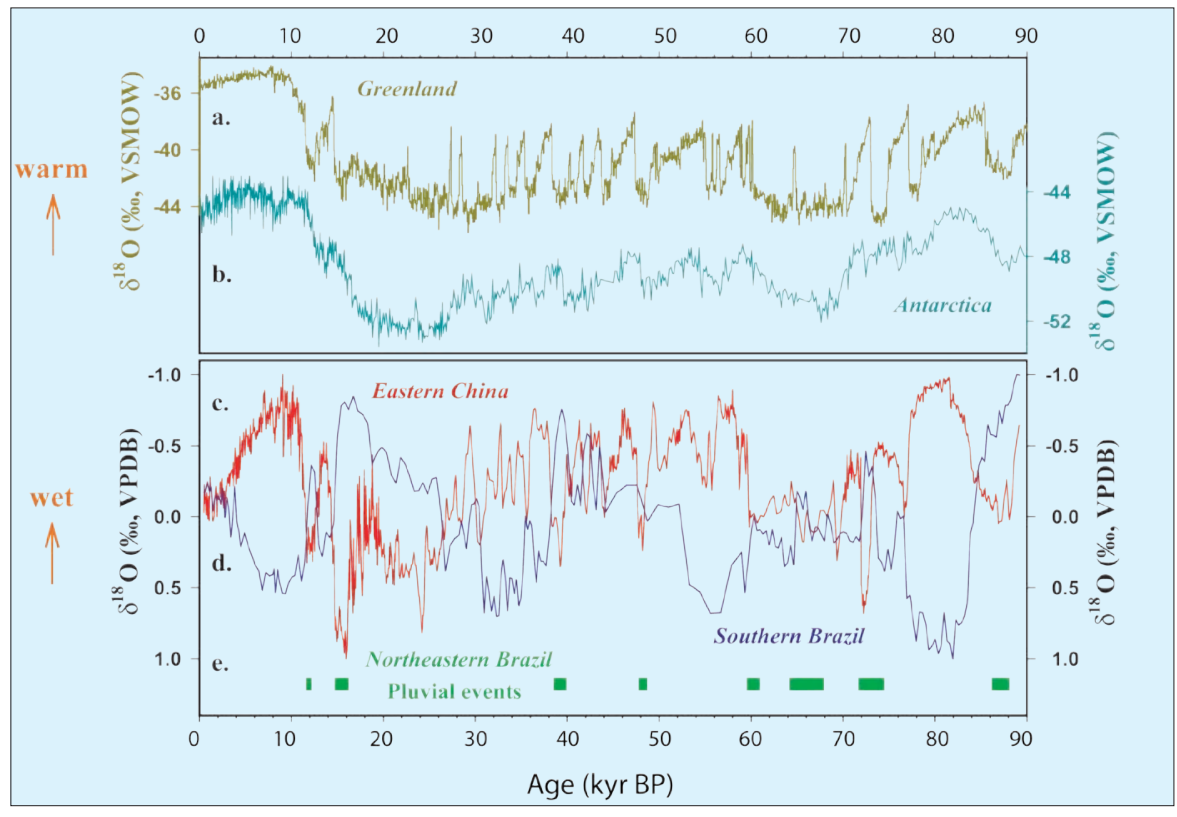

Figure 2: Comparisons of speleothem records with polar ice core records. a) NGRIP ice core record from Greenland (light green, NGRIP members, 2004); b) EDML ice core record from Antarctica (dark green, EPICA members, 2006); c) Combined profile (red) of the eastern China speleothem $\delta^{18} \mathrm{O}$ records, from Dongge Cave (Yuan et al., 2004; Wang et al., 2005), Hulu Cave (Wang et al., 2001) and Sanbao Cave (Wang et al., 2008); d) Southern Brazil speleothem $\delta^{18} \mathrm{O}$ record (blue, Caverna Botuverá, Wang et al., 2007); e) Northeastern Brazil speleothem growth periods (green, Wang et al., 2004). Note the speleothem $\delta^{18} \mathrm{O}$ records are normalized for easy comparison and scales are reversed, increasing downwards.

subtropical South Atlantic may stimulate a persistent intense South American Summer Monsoon and strong low-level jet, which consequently supplies isotopically depleted precipitation into southern Brazil (Vuille and Werner, 2005).

Moreover, analogous to modern seasonal observations in boreal winters (Lindzen and Hou, 1988), southward ITCZ migration during millennial-scale stadial events may have caused meridional asymmetry in the Hadley circulation. A southward shift of the zonal-mean Hadley cell would change meridional moisture transport through intense ascending air masses in the southern low latitudes, and increased subsidence in the northern tropics and subtropics. Broadly, the northern low latitudes would be drier and the southern low latitudes wetter, which has been confirmed by recent model results (e.g., Chiang and Bitz, 2005; Timmermann et al., 2007). The opposite scenario would have been true during glacial interstadial periods.

\section{AMOC vs. Super-ENSO mechanisms}

It is still debated whether AMOC changes or tropical air-sea interactions, such as persistent El Niño-Southern Oscillation events (Super-ENSO), triggered the millennial-scale climate events (Broecker, 2003). Phase relationships of these events in Brazilian speleothem records may have implications on their mechanisms. The modern climate in both northeastern and southern Brazil is sensitive to the ENSO phenomenon. For example, modern El
Niño events induce drought in northeastern Brazil and high precipitation in southern Brazil (Ropelewski and Halpert, 1987) (Fig. 1). If the modern ENSO behavior does not change substantially with time, the Super-ENSO scenarios may result in opposite rainfall patterns between the two regions. On the other hand, changes in the AMOC would cause a latitudinal ITCZ migration and associated changes in the Hadley circulation (e.g., Chiang and Bitz, 2005). The latter may cause in-phase precipitation changes in northeastern and southern Brazil on millennial timescales, which is confirmed by the speleothem record comparison (Fig. 2). This relationship is therefore consistent with shifts in the mean ITCZ position linked to AMOC changes but not with the Super-ENSO mechanism.

\section{References}

Broecker, W.S., 2003: Does the trigger for abrupt climate change reside in the ocean or in the atmosphere?, Science, 300: 1519-1522.

Chiang, J.C.H. and Bitz, C.M., 2005: Influence of high latitude ice cover on the marine Intertropical Convergence Zone, Climate Dynamics, 25: 477-496.

Cruz, F.W. Jr., Burns, S.J., Karmann, I., Sharp, W.D., Vuille, M., Cardoso, A.0., Ferrari, J.A., Dias, P.L.S. and Viana, O. Jr., 2005: Insolationdriven changes in atmospheric circulation over the past 116,000 years in subtropical Brazil, Nature, 434: 63-66.

Wang, X., Auler, A.S., Edwards, R.L., Cheng, H., Cristalli, P.S., Smart, P.L., Richards, D.A. and Shen, C.-C., 2004: Wet periods in northeastern Brazil over the past $210 \mathrm{kyr}$ linked to distant climate anomalies, Nature, 432: 740-743.

Wang, Y., et al., 2008: Millennial- and orbital-scale changes in the East Asian monsoon over the past 224,000 years, Nature, 451: 10901093

For full references please consult:

www.pages-igbp.org/products/newsletters/ref2008_3.html 